\title{
CONSERVATION OF THE GROUP PIPERIA (ORCHIDACEAE) AND ASSOCIATED PLANT COMMUNITIES
}

\author{
ROBERT K. LAURI \\ Rancho Santa Ana Botanic Garden, 1500 North College Avenue, Claremont, California, 91711, U.S.A. \\ robert.lauri@cgu.edu
}

KeY Words: conservation, habitat, integrated, management, Piperia, Platanthera

\section{Introduction}

The conservation and protection of California native orchids has not been a large focus recently. All California native orchids are terrestrial and many are associated with forest and woodland plant communities. However, a number are associated with the Mediterranean Climate plant community known as Chaparral; this includes at least three Piperia Rydb. species. Many Piperia populations and associated Chaparral plant communities have been impacted by human activity over the past several decades, however, there is very little documentation regarding the size, and overall impact to the populations.

Piperia contains nine recognized species and two subspecies (Ackerman 1977, Morgan \& Ackerman 1990, Morgan \& Glicenstein 1993, Hickman 1996) and has been recently placed as a subgenus of
Platanthera Rich. (Bateman et al. 2003). The overall distribution of Piperia is fairly large and the group ranges from Baja California, Mexico, to Alaska, and to the northeast, with a single population in Newfoundland, Canada (Fig. 1). Many Piperia have limited distributions with populations that are small and disjunct, such as Piperia elegans (Lindl.) Rydb. subsp. decurtata R. Morgan \& Glicenstein (Fig. 2). Piperia populations have recently been more fragmented due to human activities such as agriculture, human population expansion, and introduction of noxious weeds.

\section{Preliminary Data}

This paper focuses on conservation experiences of rare Piperia taxa in California, and highlights the successes and some failures to conserve them. The infor-

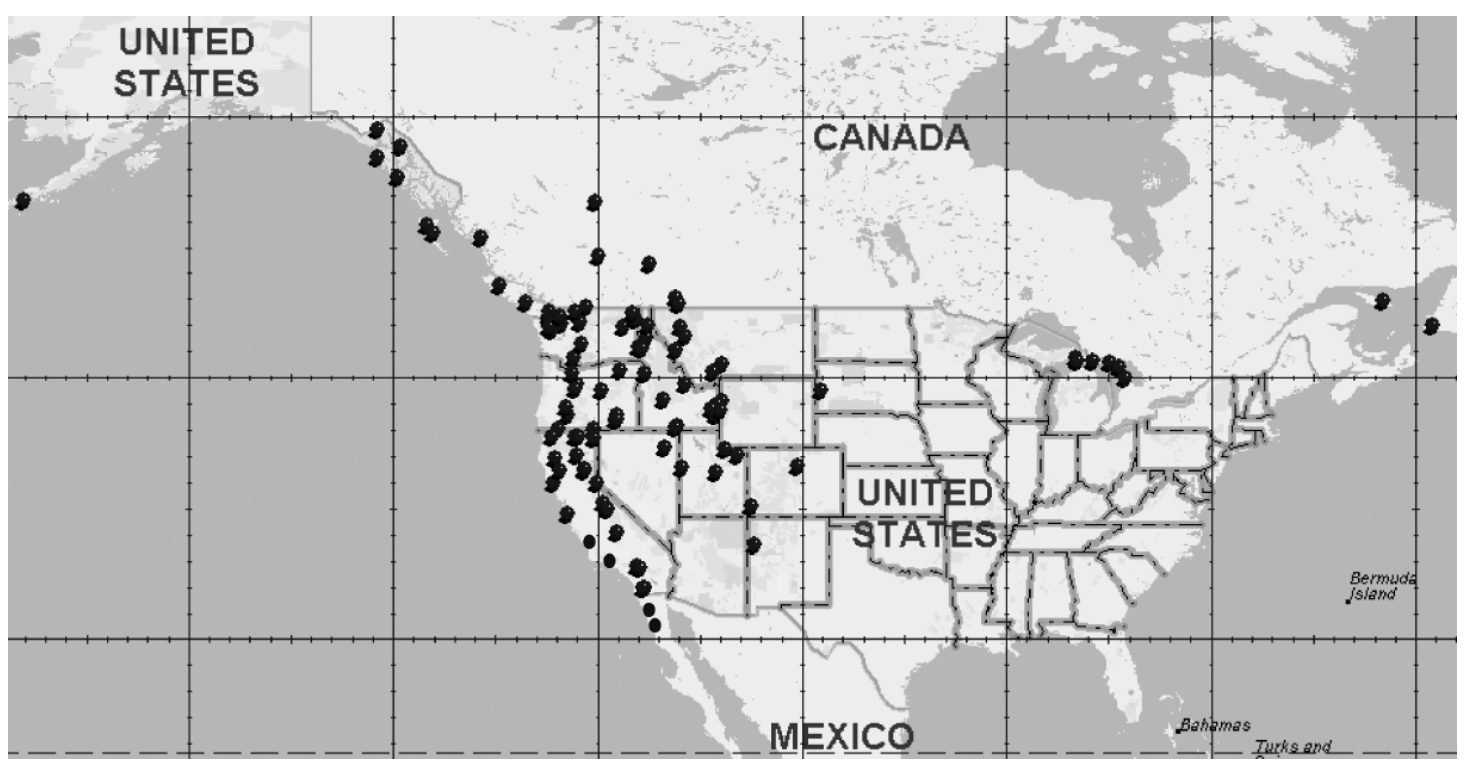

Figure 1. Various Piperia taxa population distributions. 


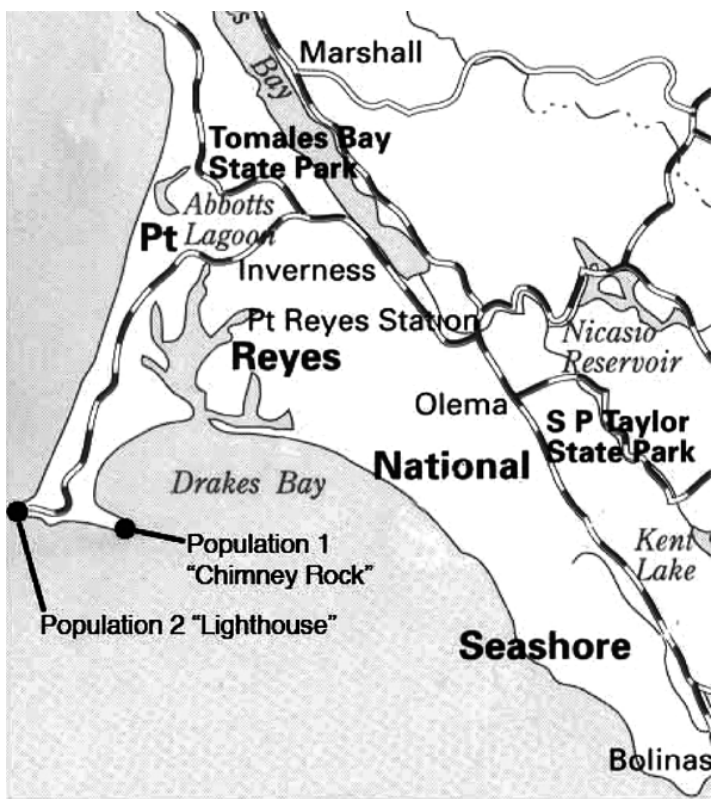

FIgURE 2. Piperia elegans subsp. decurtata population locations, Marin County, California, USA.

mation presented will be useful for the conservation of most orchids, especially terrestrial taxa. The main focus will be conservation plans for Piperia cooperi (S. Watson) Rydb., $P$. elegans ssp. decurtata, and $P$. yadonii R. Morgan \& Ackerman. The discussion also includes some preliminary molecular data including ITS markers used to correctly identify the taxa. Including molecular data can often help to identify taxa and to verify if they are monophyletic. However, not all taxa can be classified by using standard phylogenetic markers and techniques. Providing an integrated approach to conservation of these taxa, including comparative morphology, ecology, and conservation agency cooperation is often also necessary in determining what taxa should be conserved.
Using an ITS phylogeny for Piperia (Fig. 3), we can see that $P$. cooperi is separated from its sister taxa $P$. michaelii (Greene) Rydb. by a moderate bootstrap value of 63, while Piperia elegans subsp. decurtata doesn't separate out from $P$. elegans (Lindl.) Rydb. subsp. elegans, and $P$. yadonii doesn't separate out from $P$. elongata Rydb. This preliminary phylogenetic data suggest that an additional faster evolving marker, or other information should be included to separate out these taxa. This is why the inclusion of morphological, ecological, and population data is also important in determining the conservation status of rare orchid taxa.

To provide a better understanding of the relationship of these orchids will therefore provide additional data to separate out the taxa for conservation purposes. This is important because without additional data, such as population level, morphological, and ecological data, these orchids may not have sufficient protection on private lands and/or through conservation agencies. A recent example of this is a large ( $c a$. 2000-4000) population of Piperia cooperi on Point Loma in San Diego County, California, USA. This population has been documented to be the largest single population of $P$. cooperi known. This population recently was slated to be destroyed due to a grading project on U.S. federal property. This was possible because $P$. cooperi has no federal or state protection and the latest data from the California Native Plant Society (CNPS) noted that the plant is a CNPS List 4.2 plant (Table 1). I was contacted as an orchid expert to provide information to the United States federal government regarding $P$. cooperi. Because of my dissertation study, I had visited a number of the $P$. cooperi populations in southern California, and Baja California (Fig. 4A, B, C). I compiled a list of all the

TABle 1. Conservation status for three Piperia taxa. California Native Plant Society (CNPS) List 1B.1: rare, threatened, or endangered in California and elsewhere, seriously endangered in California; CNPS 4.2: limited distribution (watch list), fairly endangered in California. State rank: S1: less than five occurrences or less than 1000 individuals or less than 2000 acres; S2: 6-20 occurrences or 1000-3000 individuals or 2000-10,000 acres; S3: 21-80 occurrences or $3000-10,000$ individuals or 10,000-50,000 acres.

\begin{tabular}{l|c|c|c|c|c} 
Taxon & CNPS Listing & State Rank & Global Rank & State Listing & Federal Listing \\
\hline Piperia cooperi & 4.2 & $\mathrm{~S} 3.2$ & G4 & None & None \\
\hline Piperia elegans subsp. decurtata & $\begin{array}{c}\text { 1B.1 } \\
\text { CA - Endemic }\end{array}$ & S1.1 & G4T1 & None & None \\
\hline Piperia yadonii & $\begin{array}{c}\text { 1B.1 } \\
\text { CA - Endemic }\end{array}$ & S2.1 & G2 & None & $\begin{array}{c}\text { Federally } \\
\text { Endangered }\end{array}$ \\
\hline
\end{tabular}




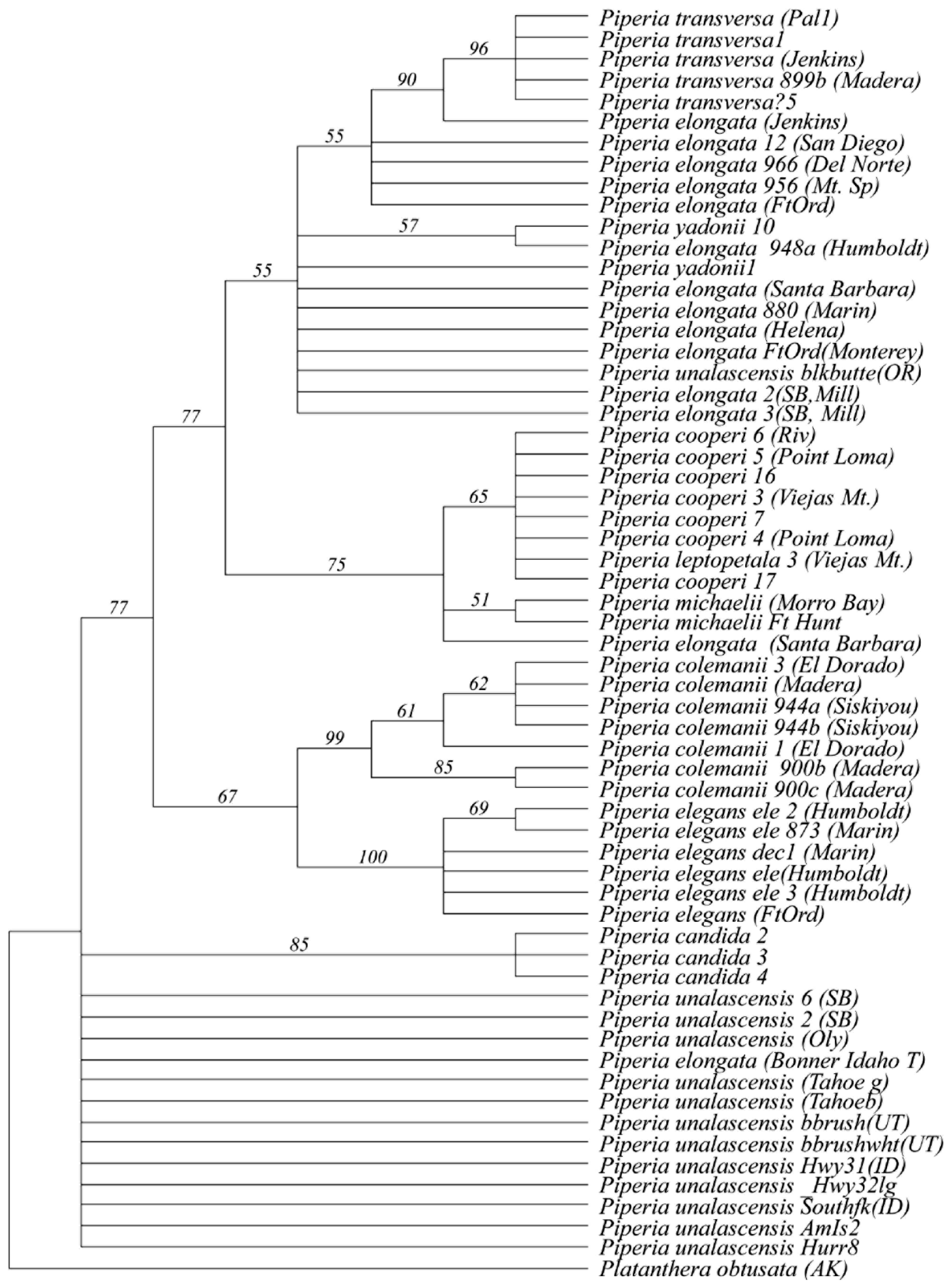

FIGURE 3. ITS parsimony bootstrap consensus tree of 63 samples of Piperia from California, Baja California, and the western United States 


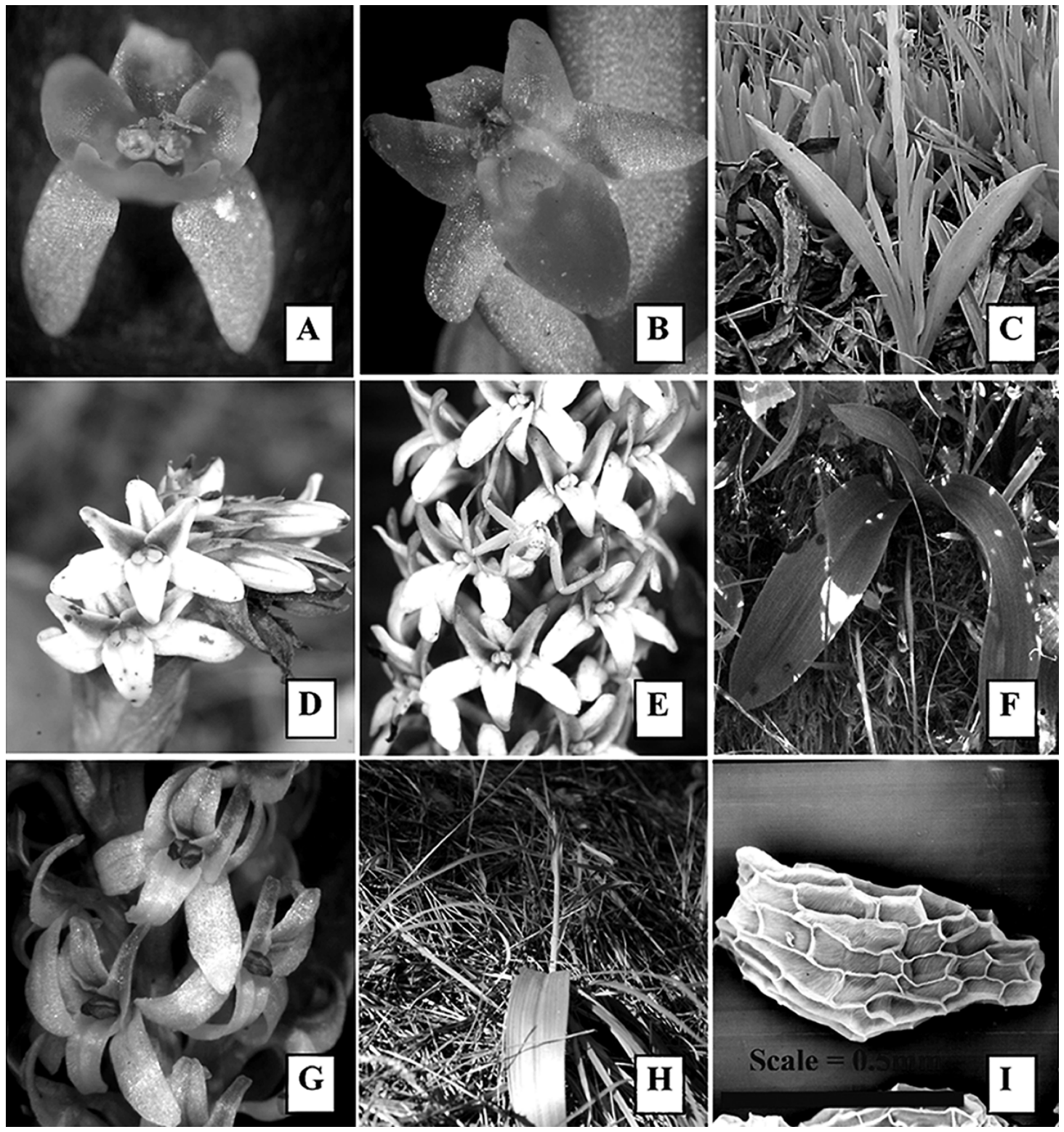

Figure 4. Piperia cooperi A. Flower (coastal form). B. Flower (inland form). C Leaves. Piperia elegans subsp. decurtata D. Flower. Piperia elegans subsp. elegans E. Flower. Piperia elegans subsp. decurtata F. Leaves. Piperia yadonii G. Flower. H. leaves. I. Seed.

known P. cooperi populations and cross-referenced these data that I had collected regarding the known populations. I presented the data to the biological representatives of the U.S. federal government noting that of 118 documented populations of $P$. cooperi, approximately 40 could not be found and are presumed not extant due to human impacts. Of the remaining 78 populations, only $50 \%$ recently have been re-documented. The vast majority of the populations that have not been seen in over 30 years, though, are presumed extant because the habitat in the area is in good condition. I also provided information that only six newly documented population of $P$. cooperi had been found in the last 30 years. The collection of this data assisted the U.S. federal government in determining that the populations of $P$. 
cooperi had been impacted more than was thought from the data previously collected. The botanical community in southern California is now actively searching for historically documented and undocumented populations of $P$. cooperi and counting individuals per population in order to reassess the CNPS and global ranking of this taxon. A request to change the CNPS status of this orchid from CNPS List 4.2 (limited distribution, fairly endangered) to a 3.1 (more information needed; review list, seriously endangered) has been filed with the California Department of Fish and Game.

Piperia elegans subsp. decurtata is another rare California orchid that has had some conservation success in recent years. This subspecies of the more common P. elegans subsp. elegans occurs in two populations within the Point Reyes National Seashore (PRNS) in Marin County, California, USA (Fig. 2). The two subspecies differ morphologically by $P$. elegans subsp. decurtata (Fig. 4D) having a short nectary spur (4-6 cm long) when compared with $P$. elegans subsp. elegans (Fig. 4E) (7-18 mm long). This taxon was originally given a total number of individuals at approximately 500 (Morgan \& Glicenstein 1993). Since that time, a concerted effort to perform annual individual counts has taken place. To this date, the largest number of flowering individuals counted has been 32 in the elephant seal population, and 108 in the lighthouse population (Table 2, R. Lauri, unpubl. data). There are a number of individual $P$. elegans subsp. decurtata that have not bloomed in this time period. These individuals have been located during spring surveys when searching for leaf rosettes that are present before bloom (Fig. 4F). During bloom time, the leaf rosettes senesce and are impossible to locate in non-blooming plants. The individual plant counts are conducted to get an accurate count of the total individuals in each population, and to verify the hypothesis that approximately $10-15 \%$ of the individuals in a population flower in any given year. The largest single flowering event occurred in 2005, primarily due to an El Niño series of storms that provided the area with twice the annual rainfall. These storms also brought a warm winter season that produced large rosette growth, and an extended rainfall season that allowed greater than normal inflorescence initiation, at the same time there was less impact from
TABle 2. Piperia elegans subsp. decrutata population census data.

\begin{tabular}{lcc} 
Date of Census & $\begin{array}{c}\text { Elephant Seal } \\
\text { Population }\end{array}$ & $\begin{array}{c}\text { Lighthouse } \\
\text { Population }\end{array}$ \\
\hline $8 / 31 / 2000$ & 32 & 11 \\
\hline $8 / 21 / 2001$ & 1 & 1 \\
\hline $8 / 19 / 2002$ & 3 & 64 \\
\hline $8 / 19 / 2003$ & 28 & 0 \\
\hline $8 / 2004$ & No data & No data \\
\hline $8 / 2005$ & 0 & 108 \\
\hline $8 / 2006$ & 3 & 4 \\
\hline
\end{tabular}

by deer as there was more browsing vegetation. The preliminary individual plant counts are not conclusive because the total number of individuals per population or percent bloom of total individuals has not been verified. However, the added interest of the individual plant counts has generated greater involvement within the local Marin Chapter of the California Native Plant Society, who have assisted with the plant counts, and to are continuing to advocate for the conservation of the two populations. The Point Reyes National Seashore also has become more aware of conservation issues surrounding this taxon in conjunction with the need to protect a portion of the elephant seal population during expansion of an access path to the elephant seal overlook. This has caused the initiation of a conservation plan for P. elegans subsp. decurtata (Lauri, in review), to allow a more active role for all conservation groups in the longterm survival of this taxon.

The only Piperia provided Federal Endangered Listing is Piperia yadonii (Fig. 4G, H). This Piperia is endemic to a very small area of Monterey County, California, USA. Because $P$. yadonii as a restricted endemic range, and is in close proximity to human development, it has been given this special status, even though it is projected that there are over 100,000 individuals (Doak \& Graff 2001). Most of the individual orchids are located on private property. Piperia yadonii is very closely related to $P$. elongata, and the preliminary ITS data does not separate the two taxa (Fig. 3). The ITS data also suggests that $P$. transversa Suksd. also is closely related to both $P$. yadonii and $P$. elongata. P. yadonii was recently described (Ackerman \& Morgan 1990), with an approximate population estimated at 5000 individu- 
als. A number of individual plant and population counts have occurred around the Monterey Peninsula. These individual plant counts indicate that from 0.4 to $22 \%$ of the vegetative individuals flower in a given year (Graff 2006). This provides us with a total individual orchid count of over 100,000. Even with all populations documented and counted, and the orchids provided Federal Endangered status protection, the local botanical community of Monterey was not satisfied that the orchids were afforded appropriate conservation measures. The United States Fish and Wildlife Service (USFWS) has been compelled to address the conservation of the habitat and plant community that the orchids inhabit. A draft habitat conservation plan has been proposed (USFWS, unpubl.), that addresses the issues of conservation for particular $P$. yadonii populations and surrounding habitat to allow the continued existence and even expansion of this taxon. However, this plan also leaves a number of populations and habitats unprotected due to the U.S. federal government's wish not to over regulate individual landowners and small municipalities. I have reviewed the draft habitat conservation plan and provided the following input to the USFWS. This information is being made public (USFWS, Ventura Office Website 2007). The habitat conservation plan addresses the issue of conserving the largest populations of $P$. yadonii and protecting their habitat, however, there is no information regarding gene flow, specifically the transfer of pollen from one population to the next nor the movement of seed within and between populations. The pollinator of $P$. yadonii are nocturnal moths in the families Pyralidae, Geometridae, Noctuidae, and Pterophoridae (Doak \& Graff 2001); however, no study or presentation of data from a Lepidoptera expert has been presented that would address the issue of how far a pollinator can travel and whether there is the possibility of transferring pollen from nearby populations. There also are no data regarding how far Piperia seed can travel. It has been hypothesized that the size and shape of orchid seed is conducive to movement by wind and that the vast majority of seed travels only within six meters of the parent plant (Chung et al. 2003). This supports the data that most orchid seeds don't remain in the air for long and fall $1.5 \mathrm{~m} / \mathrm{s}$ in 8 seconds, and suggest that theses seeds are not extremely buoyant (Arditti \& Ghani 2000). However, Piperia seeds may be fairly buoyant due to the raised cell wall on the seed coat (Fig. 4I). These data suggest that a pattern may occur for $P$. yadonii that is similar to other terrestrial orchid taxa, in that there is low genetic diversity within populations, due to limited seed dispersal, and higher genetic diversity between populations. It is therefore crucial to conserve as many populations of $P$. yadonii as possible in order to retain genetic diversity in all populations of $P$. yadonii and to avoid a population crash due to reduced genetic diversity and gene flow. It has been observed that most Piperia produce more viable seed when outcrossed to another individuals, or another taxon, when compared to selfing (Ackerman 1976, Doak \& Graff 2001). I have requested a complete study of the population dynamics and population genetics of $P$. yadonii to provide a more complete understanding of the conservation needs of this taxon. This will include individual sampling of specimens from all known populations. In addition, I have requested that an in-depth ecological sampling be taken of the plant communities in and around the $P$. yadonii populations. This will include determining the density and diversity of all vegetation layers associated with the orchid populations, and classification of each of the plant communities found. The ecological habitat study will assist the conservation agencies and landowners in determining a more accurate description of the habitat critical to the conservation of this taxon and associated plant taxa.

\section{Conclusion}

These three examples of Piperia conservation are good models for continued efforts in terrestrial and epiphytic orchid conservation research. These examples provide instances of initiating conservation goals and collecting evidence to show conservation needs. In addition, once rarity and need have been determined for a taxon, it is clearer what next steps should be taken to conserve the taxa, such as the development of conservation plans followed by annual monitoring of the taxa. Finally, once the taxon has been given protection, there are additional factors to take into account, such as protecting the habitat that the orchid taxon is associated with, as well as specific pollinators. Having molecular data to assist in sepa- 
rating out taxa for conservation can be helpful; however, following a total evidence approach to conservation is most successful. This approach can aid in providing additional evidence for the conservation need of orchid taxa, when molecular evidence is inconclusive.

Acknowledgements. Rancho Santa Ana Botanic Garden: Mark Porter, Linda Prince, Linda Warlow, Sarah DeGroot; California Native Plant Society, Marin Chapter: Doreen Smith, Bob Soost; Point Reyes National Seashore: Jane Rodger;s San Diego State University: Michael G. Simpson, Dina Estrella; San Diego Natural History Museum: Jon P. Rebman; University of Puerto Rico: James D. Ackerman; United States Fish and Wildlife Service: Diane Steeck.

\section{Literature Cited}

Ackerman, J.D. 1976. Biosystematic studies in the genus Piperia (Orchidaceae). Master of Arts Thesis, Humboldt State University, Arcata, California, USA.

Ackerman, J.D. 1977. Biosystematics of the genus Piperia Rydb. Bot. J. Linn. Soc. $75: 245-270$.

Arditti, J. \& A.K.A Ghani 2000. Tansley Review No. 110 Numberical and physical properties of orchid seeds and their biological implications. New Phytol. 145.
Bateman R.M., P.M. Hollingsworth, J. Preston, Y. Luo, A.M. Pridgeon \& M.W. Chase. 2003. Molecular phylogenetics and evolution of the Orchidinae and selected Habenariinae (Orchidaceae). Bot. J. Linn. Soc. 142 : 1-40.

Chung, M.Y., J.D. Nason \& M.G. Chung. 2004. Spatial genetic structure in populations of the terrestrial orchid Cephalanthera longibracteata (Orchidaceae). Amer. J. Bot. 91 : 52-57.

Doak, D.F. \& A. Graff. 2001. Reproductive biology and pollination ecology of the federally endangered Yadon's piperia (Piperia yadonii, Orchidaceae) in Monterey County, California. Report prepared for the U.S. Fish and Wildlife Service, Ventura Field Office, Ventura, California.

Graff, A. 2006. A long-term monitoring program for the federal endangered Yadon's rein orchid (Piperia yadonii, Orchidaceae). Report submitted to the Ventura Fish and Wildlife Office, Ventura, California, USA.

Hickman, J.C. (ed.). 1996. The Jepson Manual: higher plants of California. University of California Press, Berkeley, California, USA.

Morgan, R. \& J.D. Ackerman. 1990. Two new Piperias (Orchidaceae) from western North America. Lindleyana 5(4) : 205-211.

Morgan, R. \& L. Glicenstein. 1993. Additional California taxa in Piperia (Orchidaceae). Lindleyana 8( 2): 89-95.

United States Fish and Wildlife Service. 2007. Ventura, California, USA. Website available at: http://www.fws.gov/ventura.

Robert K. Lauri is a Ph.D. candidate at Rancho Santa Ana Botanic Garden, California, USA. He is currently working on his dissertation, "The Systematic and Phylogenetic Study of Piperia." He also has earned his master's degree at San Diego State University, California, USA. His master's thesis was titled "The Comparative Floristic Study of Palomar Mountain State Park." In his career, he has specialized in habitat restoration, rare plant surveys, plant community mapping and identification. He is using this broad range of knowledge to work on the production of orchid conservation plans and the review of conservation guidelines for rare and endangered orchids. 